\title{
Implementation of Character Education: Impacts on Students and School Components at Madrasah Aliyah Negeri (MAN) Insan Cendekia Gorontalo
}

\author{
Imas Baguna \\ Bina Mandiri University Gorontalo, Indonesia \\ Received: October 29, 2020 \\ Revised: November 7, 2020 \\ Accepted: November 12, 2020
}

\begin{abstract}
This study aims to determine the implementation of special character education on the impact for students and school components at Madrasah Aliyah Negeri (MAN) Insan Cendekia Gorontalo. This research method is a qualitative field research. Data collection was carried out through preliminary or pre-observational studies, observations, and interviews. The characters developed in this madrasa include disciplined, religious, polite, responsible, hard work and cooperation. In other words, this character development is carried out in the madrasah program of activities both through learning, as well as extra $\neg$ curricular as well as religious and self-development activities. The impact of the results of the implementation of character education at MAN Insan Cendekia Gorontalo has a positive impact for all groups, especially for students and the school community. The impact of character education for school components. The implementation of character education at MAN Insan Cendekia Gorontalo is very beneficial for students, due to changes in attitudes that are even better and according to the expectations of parents, where their children live disciplined, productive, independent and able to practice religious teachings.
\end{abstract}

Keywords: Character Education, Students, School Components

\section{Introduction}

Education is something that is urgent in advancing a nation in addition to being considered a standard for state progress, education also represents the needs of each individual in developing knowledge, skills, attitude, and increasing credibility in society (Elmore, 2002). Even education is an important part of the national development process that determines the economic growth of a country and is also an investment in human resource development, in increasing skills and abilities which are believed to be supporting factors for human efforts in improving the quality of education (Kellaghan \& Greaney, 2001 ; Davies et al., 2005; Subroto, 2013). In the process of national character education, students actively develop their potential, carry out the internalization process, and live the values into their personalities in socializing in society, develop dignified community and national life (Kanu, 1996; Datuk, 2020 ). The development of character education is very strategic for the sustainability and excellence of the nation in the future.

The development must be carried out with appropriate planning and approach, and effective learning methods. Character education is seen as something very important and urgent to implement for reasons of various social situations (Freeth et al., 2008; Agboola \& Tsai., 2012). This situation, such as the influence of the development of consumerism values, hedonism, free sex, drug abuse, and often the users also still have student status, violence, an outlet for human desires that no longer heed the need for the value of faith and piety. 
Worse, there are children who dare to kill their own parents. On the other hand, there has also been a decline in collective character so that there have been many fights between pockets, fights between villages, between religions, between races, emphasizing the interests of groups, groups and parties above the public interest. The free market situation based on neoliberalism has caused the weak and powerless to be increasingly marginalized and wasted in humiliation. Meanwhile, the economically strong are increasingly indifferent, unwilling to share and no longer empathetic. If there is empathy, it is only lips service and hope that his good deeds are published in newspapers and widely publicized.

The multi-dimensional crisis that is being experienced by the Indonesian nation has had a major impact on various orders of national life. If this is not noticed and a solution is sought quickly and precisely, it seems that the Indonesian nation will not be able to rise. Attention to character education has also been seen from the thoughts of predecessor education figures. This means that character education is not something new in the world of education in Indonesia.

The direction and policies and priorities of character education emphasize that character education has become an integral part of the efforts to achieve the national development vision as stated in the 2005-2025 Long-Term Development Plan. Related to this, in order to carry out the functions and objectives of character education, Permendiknas Number 23 of 2006 concerning Graduate Competency Standards (SKL) has been issued. If we look closely, in fact, almost every formulation of the SKL is implicitly or explicitly, both for the SKL SD / MI, SMP / MTs, SMA / MA and SMK, containing the substance of values / characters.

In the school curriculum structure, basically every subject contains material related to character. Substantively, there are at least two subjects that are directly related to the development of character and noble character, namely Religious education and Citizenship education (Civics). Both of these subjects are subjects that directly (explicitly) introduce values, which to a certain extent make students care and internalize values / characters. The integration of character education in these subjects leads to the internalization of values in everyday behavior.

Character education is not new at Madrasah Aliyah Negeri (MAN) Insan Cendekia Gorontalo. MAN Insan Cendekia Gorontalo, as one of the formal education institutions, operates a boarding school system. This system is one of the features of MAN Insan Cendekia Gorontalo because it provides 24-hour assistance to its students. While in the dormitory environment, students are accompanied intensively by the dormitory supervisor. Thus, the spiritual aspect and the development of Islamic personality are superior aspects besides the achievement of academic achievement and also as an implementation of the implementation of explicit character education. This study aims to determine the implementation of character education specifically on the impact for students and school components at Madrasah Aliyah Negeri (MAN) Insan Cendekia Gorontalo.

\section{Methods}

This research is a qualitative field research (field research). This research is concerned with character-based education at MAN Insan Cendekia Gorontalo. This research was conducted at Madrasah Aliyah Negeri (MAN) Insan Cendekia Gorontalo, which is located in Moutong Village, Tilong Kabila District, Bone Bolango Regency, Gorontalo Province.

The approach used in this research is a qualitative approach and a scientific approach which includes normative theological, pedagogical, sociological, managerial, this approach is intended 
to examine the existence of MAN Insan Cendekia Gorontalo organizationally in the midst of efforts to improve the overall quality of education. Good quality related to soft skills and hard skills. Data collection was carried out through preliminary studies or pre-observation through documentation, observation and interviews. Data analysis through data reduction, data presentation and drawing conclusions.

\section{Results and Discussion}

\section{The Impact of Character Education for Students}

The impact or the results of the implementation of character education at MAN Insan Cendekia Gorontalo has a positive influence for all circles, especially for students and the school community. 38 of 2008 concerning Student Development. The school is expected to have programs or activities that can deliver students to have the competence to be able to compete or excel in both academic and non-academic fields.

The program of the activities is also expected to develop the character, personality, discipline, talents, interests and competences of students. According to the Head of MAN Insan Cendekia Gorontalo that coaching activities for students in order to develop character values such as courage, confidence, obedience, communicative, sympathetic, competitive, able to lead and work together are carried out in the form of achievement, motivation, training in various forms such as public speaking, leadership, assertive communication, social service and outbound, these activities are carried out by paying attention to the academic calendar.

Student coaching activities are carried out on a daily basis and are scheduled. In addition, this activity is carried out in a measured manner using competency standards. Each grade level, both classes X, XI and XII have their own standards, so for the clarity of the intended student coaching activities are described in tables 18,19 and 20 on the previous page. In the table there are four activities carried out to build competence, cooperation, interpersonal relationships, discipline and leadership abilities, all of which are part of the character of students built in MAN Insan Cendekia Gorontalo.

In addition, the implementation of character education at MAN Insan Cendekia Gorontalo makes students have character while being able to achieve graduate competency standards (SKL). Facts in the field show that based on government policies in this case the Ministry of National Education and school principals, as well as the strategies adopted by all education staff in developing character education for MAN Insan Cendekia students have succeeded as students with character and at the same time able to achieve the competency standards of graduates (SKL) determined by the government based on the attachment to Permendiknas No. 23 of 2006 concerning the Substance of Character Value included in SKL.

From the information interviewed, it can be understood that character education in students has changed in various aspects which have an impact on the formation of students with character so that they can reach the graduate competency standard (SKL). One indicator of achieving SKL is the number of alumni who continue their education at the tertiary level. Furthermore, it can be seen that the alumni of MAN Insan Cendekia Gorontalo in the 2011-2012 academic year are 99 people who have continued to various universities, namely Brawijaya University as much as $27 \%$, Negei Islamic University as much as 16\%, Airlangga University as much as $4 \%$, Hasanuddin University Makassar. as much as 7\%, Bogor Agricultural Institute as much as 8\%, 
University of Indonesia as much as 7\%, Semarang Institute of Technology as much as 3\% and other universities as much as $27 \%$.

The impact of character education on MAN Insan Cendekia Gorontalo implements the character building program of Students through various activities, both through learning in class and through extracurricular religious activities and self-development so that all students or alumni of MAN Insan Cendekia Gorontalo always behave well or have character as expected. expected. Thus the aim of character education is implemented at MAN Insan Cendekia Gorontalo to unite the vision and mission and change the behavior of students so that they have superior character in the midst of society.

\section{Impact of Character Education for School Components}

The implementation of character education programs and activities for each institution, especially in MAN Insan Cendekia Gorontalo, has at least three principles that must be considered in cultivating character values, namely the principles of effectiveness, efficiency, and productivity. The implementation of programs and activities is said to be efficient if the results achieved are in accordance with the objectives and efficiently emphasize more if the programs and activities carried out can produce according to objectives with minimal costs or at the right cost, the results are maximum. Meanwhile, the principle of productivity is if the implementation of these programs and activities results in a qualitative and quantitative manner, in accordance with the objectives (Staats et al., 2011; Joo-Nagata., 2017). In other words, the activity of instilling character values should be proven by the results achieved.

The impact of character education for the school component is that MAN Insan Cendekia Gorontalo as a boarding madrasah has a different culture from the environment of students before they enter the madrasah. The culture that is built in this madarasah has religious nuances, emphasizes togetherness, independence and is kinship in nature.

From the results of the interview, it was found that the implementation of character education at MAN Insan Cendekia Gorontalo is very beneficial for students, because there is a change in attitudes that are even better and according to the expectations of parents, where their children live disciplined, productive, independent and able to practice the teachings of Islam without compulsion so that peace and happiness are created in the family environment and society, because children are avoided from various forms of bad attitudes that can damage the good name of the family.

According to researchers it is in line with research conducted by Hasib et al. (2017) that multicultural education is a superior part of instilling character values for students so that it can make MAN Insan Cendekia Gorontalo an international standard boarding school with various achievements and successes that have been achieved well. Even so, in the midst of the success of character education at MAN Insan Cendekia Gorontalo, there are still several obstacles in the implementation of the implementation of character values, namely in terms of exemplary, for example, there are still teachers and female employees who do not pray in congregation due to activities or busyness. they have to finish. It is better if this attitude should be eliminated in order to provide an example to students.

\section{Conclusion}

The impact of the results of the implementation of character education at MAN Insan Cendekia Gorontalo has a positive impact on all groups, especially for students and the school 
community. The impact of character education for school components, even MAN Insan Cendekia Gorontalo as a boarding school has a different culture from the environment of students before they enter madrasa. The culture that is built in this madarasah has religious nuances, emphasizes togetherness, independence and is family in nature.

\section{References}

Agboola, A., \& Tsai, K. C. (2012). Bring Character Education into Classroom. European journal of educational research, 1(2), 163-170.

Datuk, A. (2020). Internalization of Character Education in Era 4.0 as A Moral Conservation Solution for Students in Kupang City. In The 5th Progressive and Fun Education International Conference (PFEIC 2020) (pp. 21-30). Atlantis Press.

Davies, I., Gorard, S., \& McGuinn, N. (2005). Citizenship education and character education: Similarities and contrasts. British Journal of Educational Studies, 53(3), 341-358.

Elmore, R. F. (2002). Bridging the gap between standards and achievement: The imperative for professional development in education. Secondary lenses on learning participant book: Team leadership for mathematics in middle and high schools, 313-344.

Freeth, D. S., Hammick, M., Reeves, S., Koppel, I., \& Barr, H. (2008). Effective interprofessional education: development, delivery, and evaluation. John Wiley \& Sons.

Hasib, M., Nahruddin, Z., Tahir, M. M., Handam, M., Akbar, M. F., \& Nurdiansyah, W. (2017). Local Wisdom and Character Education in Youth Organizations--A Case Study of South Sulawesi Province, Indonesia. In International Conference on Administrative Science (ICAS 2017). Atlantis Press.

Joo-Nagata, J., Abad, F. M., Giner, J. G. B., \& García-Peñalvo, F. J. (2017). Augmented reality and pedestrian navigation through its implementation in m-learning and e-learning: Evaluation of an educational program in Chile. Computers \& Education, 111, 1-17.

Kanu, Y. (1996). Educating teachers for the improvement of the quality of basic education in developing countries. International Journal of Educational Development, 16(2), 173184.

Kellaghan, T., \& Greaney, V. (2001). Using assessment to improve the quality of education (p. 98). Unesco, International Institute for Educational Planning.

Staats, B. R., Brunner, D. J., \& Upton, D. M. (2011). Lean principles, learning, and knowledge work: Evidence from a software services provider. Journal of operations management, 29(5), 376-390.

Subroto, W. T. (2013). Entrepreneurship development course to foster character merchandise in support economic growth. Asian Economic and Financial Review, 3(6), 762. 